\title{
Pengaruh Pemberian Ekstrak Daun Sirih (Piper betle L.) untuk Mengendalikan Damping-Off pada Tanaman Cabai (Capsicum annum)
}

\author{
DOI 10.18196/pt.2015.040.60-66
}

\author{
Taufiq Hidayat*, Supriyadi, Sarjiyah \\ Program Studi Agroteknologi, Fakultas Pertanian, Universitas Muhammadiyah Yogyakarta, \\ Jl. Lingkar Selatan, Kasihan, Bantul, Yogyakarta 55183, Indonesia Telp. 0274387656 , \\ ${ }^{*}$ Corresponding author, e-mail: taufiqre08@gmail.com
}

\begin{abstract}
ABSTRAK
Sclerotium rolfsii merupakan penyebab penyakit damping-off pada tanaman cabai yang sulit untuk dikendalikan. Penggunaan pestisida kimia sintetik ternyata dapat menimbulkan kerusakan lingkungan. Oleh karena itu, perlu dicari alternatif pengendalian yang ramah lingkungan, salah satunya adalah penggunaan pestisida nabati dari daun sirih. Penelitian ini bertujuan untuk mendapatkan konsentrasi dan lama perendaman benih cabai yang paling baik di dalam larutan ekstrak daun sirih untuk mengendalikan penyakit damping-off yang disebabkan oleh jamur S. rolfsii. Penelitian ini terdiri dari dua tahap. Tahap pertama adalah isolasi dan perbanyakan cendawan penyebab penyakit damping-off pada tanaman cabai, yang dilaksanakan di laboratorium. Tahap kedua adalah pengujian efektifitas ekstrak daun sirih untuk mengendalikan penyakit damping-off melalui teknik perendaman benih, yang dilaksanakan di Greenhouse. Penelitian ini disusun dengan rancangan acak lengkap (RAL) dengan rancangan percobaan faktor tunggal yang terdiri dari 13 perlakuan yaitu; ekstrak daun sirih dengan konsentrasi 0\%, 40\%, 60\% dan 80\% dengan lama perendaman 1 jam, 2 jam dan 3 jam. Metode aplikasi ekstrak daun sirih yang digunakan adalah perendaman benih. Hasil penelitian menunjukkan bahwa perlakuan ekstrak daun sirih 60\% dengan lama perendaman 1 jam merupakan perlakuan yang paling baik untuk mengendalikan penyakit damping-off yang disebabkan oleh cendawan S. rolfsii.

Kata kunci: Pestisida organik, Piper betle L., Damping-off, Tanaman cabai
\end{abstract}

\begin{abstract}
Sclerotium roflsii is the causal agent of damping-off disease on pepper which difficult to control. The use of chemical pesticides cause several damage to the environment. The used of Piper betle leaves extract which is contains antifungal compounds becomes one of the solution. The aim of this study to obtain the optimum concentration of piper betle leaves extract and dipping periode of chili seed in leaves extract to control damping off disease caused by Sclerotium rolfsii. The study consists of two experiments. The first experiment was isolation and multiplication of damping off disease in chilli, this stage was conducted in laboratorium. The second experiment was performed to investigate effectivity of piper betle leaf extract to control damping off using dipping method, this stage conducted in greenhouse. The study arranged in Completely Randomized Design (CRD) with single factor experimental design consist of 13 treatment, namely consentration of 0\%, 40\%, 60\% and 80\% Piper betle leaves extract (v/V) with 1 hour, 2 hour, and 3 hour dipping time. The result showed that Piper betle leaves extract of 60\% with 1 hour dipping time had the best ability among the other treatment to control damping off disease cause of Sclerotium rolfsii in chili seedlings.

Keywords: Organic pesticides, Piper betle L., Damping off, Chili papper plant
\end{abstract}

\section{PENDAHULUAN}

Cabai merah (Capsicum annum) merupakan tanaman hortikultura semusim untuk rempahrempah yang diperlukan oleh seluruh lapisan masyarakat sebagai penyedap masakan dan penghangat badan. Luas pertanaman cabai di Indonesia pada tahun 2010 sebesar 237.105 ha dengan produksi 1.328.864 ton dan merupakan usaha budidaya terbesar di Indonesia bila dibandingkan dengan komoditas hortikultura lainnya (Septana dkk., 2012).
Budidaya cabai merah mengalami banyak gangguan yang salah satunya berasal dari faktor biotik seperti serangan jamur, bakteri dan virus yang menyebabkan kehilangan hasil panen dalam jumlah besar. Salah satu serangan jamur adalah busuk pangkal batang yang disebabkan oleh Sclerotium rolfsii. Soesanto (2008), melaporkan bahwa S. rolfsii sulit ditanggani karena mampu bertahan selama bertahun-tahun dalam tanah dalam bentuk sklerotium dan mempunyai 
kisaran inang yang luas. Menurut Sugiharso dan Suseno (1985) penyakit rebah kecambah yang disebabkan oleh S. rolfsii dapat menyebabkan kerugian sampai $80 \%$ pada persemaian cabai. Bahkan apabila keadaan lingkungan cocok untuk perkembangan penyakit ini, kerugian dapat mencapai $100 \%$

Petani seringkali mengendalian penyakit rebah kecambah dengan pemberian pestisida terhadap benih maupun pada media tanam. Benih direndam dengan menggunakan fungisida berbahan aktif Hexaconazol, propiconazol, tebuconazol, difenconazol, dan carbendazim (Madhavi, 2011). Bahan aktif yang terkandung dalam pestisida kimia bersifat persisten dalam tanah sehingga dapat menyebabkan penurunan jumlah populasi, keragaman dan aktivitas mikroorganisme tanah bahkan dapat mematikan mikroorganisme tersebut. Kematian mikroorganisme tanah menyebabkan berkurangnya kesuburan tanah, karena mikroorganisme tanah akan berkaitan langsung dalam siklus hara tanah. Oleh sebab itu perlu dicari alternatif lain untuk mengendalikan penyakit damping-off, Salah satu diantaranya adalah dengan mengunakan fungisida nabati yaitu bahan yang berasal dari tumbuhan (Friska, 2008).

Bahan tanaman yang diduga mengandung senyawa anti bakteri dan anti jamur salah satunya adalah daun sirih. Daun sirih mengandung minyak atsiri, yang terdiri dari 82,8\% senyawa fenol, dan hanya 18,2\% merupakan senyawa bukan fenol (Koesmiati, 1996). Minyak atsiri tersebut berupa adalah betlephenol, eugenol, salinen, farnesen, metil eugenol dan germaceren (Sexena, 2014). Mekanisme kerja zat anti fungal adalah dengan cara menghambat metabolisme, mengakumulasi globula lemak di dalam sitoplasma, mengurangi jumlah mitokondria, merusak membran nukleus cendawan, dan mereduksi miselium, sehingga terjadi pemendekan pada ujung hifa dan pada akhirnya miselium akan mengalami lisis (Nurmansyah, 2004).

Beberapa penelitian sebelumnya menunjukkan bahwa daun sirih memiliki kemampuan untuk mengendalikan penyakit akibat cendawan. Nurhayati (2007) membuktikan bahwa ekstrak daun sirih mampu mematikan cendawan Colleotricum capsici lebih baik bila dibandingkan dengan ekstrak biji jarak, kulit jeruk, daun dan biji nimbi, laos serta brotowali. Aisyah $d k k$. (2008) menyatakan bahwa ekstrak daun sirih dengan konsentrasi 40\% dapat menghambat cendawan Pythium sp secara in vitro. Penelitian Zaidun (2006) Penggunaan ekstrak daun sirih dan rimpang lengkuas mampu menekan intensitas penyakit blas pada tanaman padi yang disebabkan oleh Pyricularia oryzae pada tanaman padi dari $35,2 \%$ menjadi $19,2 \%$. Pengguaan eksrak daun sirih dan rimpang lengkuas mampu menekan perkembangan penyakit bercak daun kacang tanah dari 48,9\% menjadi $17.7 \%$.

\section{BAHAN DAN METODE}

Penelitian dilaksanakan di Laboratorium Bioteknologi dan Green house Fakultas Pertanian Universitas Muhammadiyah Yogyakarta. Penelitian ini disusun menggunakan rancangan acak lengkap (RAL) faktor tunggal, yang terdiri dari 9 perlakuan, yaitu pemberian Ekstrak daun sirih konsentrasi 0\%, 40\%, 60\% atau 80\% dengan lama perendaman 1 jam, 2 jam atau 3 jam. Setiap perlakuan terdiri dari 3 ulangan, setiap unit percobaan terdiri dari 20 benih cabai. Benih cabai yang digunakan adalah varietas Branang yang diperoleh dari Unit Pelaksana Teknis Dinas Balai Pengembangan Perbenihan Tanaman Pangan dan Hortikultura (UPTD BPPTPH) Yogyakarta dengan daya berkecambah $80 \%$. 


\section{Isolasi Sumber Penyakit}

Sumber penyakit diperoleh dari beberapa sentra penanaman cabai merah, cabai merah yang terinfeksi diisolasi menggunakan medium potato dextrose agar (PDA). Isolat yang didapatkan kemudian dimurnikan dan diperbanyak pada media potato dextrose cair (PDC) dan dishaker selama 72 jam pada kecepatan $135 \mathrm{rpm}$. Uji pendahuluan dilakukan dengan menyemprotkan cendawan yang telah diperbanyak pada persemaian cabai. Isolat yang menimbulkan kematian paling banyak diidentifikasi lebih lanjut secara makroskopis dan mikroskopis.

\section{Perbanyakan Cendawan}

Perbanyakan isolat Sclerotium rolfsii untuk menginokulasi media tanam dilakuan dengan menanam 5 sklerotium pada media biakan corn meal sand kemudian diinkubasi selama 12 hari pada suhu ruang (Fery, 1993). Kegiatan perbanyakan cendawan ini dilakukan secara aseptik.

\section{Persiapan Media Tanam}

Media semai terbaik untuk infeksi patogen penyebab rebah kecambah adalah media pasir, tanah dan pupuk kandang dengan perbandingan 2:1:1 (Mulyati, 2009). Campuran tersebut disterilkan dengan menggunakan autoclave selama 1 jam, kemudian didinginkan selama 15 menit. Setelah disterilkan tanah dikeringanginkan di dalam ruangan tertutup dengan sirkulasi udara yang baik, setelah itu tanah diisi ke dalam bakbak perkecambahan. Bak perkecambahan yang akan digunakan terbuat dari bak plasitk berukuran $30 \times 21 \times 5 \mathrm{~cm}$.

\section{Inokulasi cendawan patogen}

Inokulasi dilakukan dengan mencampur Corn Meal Sand yang telah mengandung Sclerotium rolfsii dan media tanam dengan perbandingan
10:1 (b/b). Media yang telah diinokulasi dibiarkan selama 1 minggu sebelum digunakanuntuk media semai.

\section{Persiapan Ekstrak Daun Sirih}

Daun sirih segar yang memiliki ukuran hampir sama dicampur dengan air dengan perbandingan 1:1 (g/v) dan kemudian diblender. Larutan ekstrak daun sirih diinkubasi selama 24 jam pada suhu kamar, setelah itu disaring dengan kain kasa. Larutan hasil penyaringan memiliki konsentrasi ekstrak daun sirih 100\%. Larutan ekstrak daun sirih 100\% kemudian diencerkan sesuai perlakuan, masing-masing perlakuan membutuhkan $250 \mathrm{ml}$ larutan.

\section{Perendaman Benih dan Penyemaian}

Setiap benih cabai didesinfeksi melalui perendaman menggunakan alkohol 70\% selama 3 menit kemudian dibilas dengan air steril. Benih cabai kemudian direndam kembali dalam larutan ekstrak daun sirih sesuai dengan perlakuan yang ada. Benih disemai pada kedalaman $\pm 1 \mathrm{~cm}$ dengan jarak tanam $5 \times 5 \mathrm{~cm}$.

Parameter yang diamati meliputi pembuktian viabilitas spora, intensitas serangan, daya berkecambah, indeks vigor, koefisien perkecambahan, dan kecepatan berkecambah first count. Daya Berkecambah (DB) (\%), dihitung berdasarkan pengamatan persentase jumlah kecambah normal dibandingkan dengan jumlah total benih yang ditanam dikalikan dengan 100\%. Perhitungan daya kecambah dihentikan pada hari ke 14. Indeks vigor mengukur lama waktu hipokotil muncul dalam satuan hari setelah tanam. Perhitungan Indeks vigor (IV) dilakukan dengan menggunakan rumus (Copeland, 1976). Koefisien perkecambahan mengukur jumlah kecambah normal dan perbedaan waktu yang 
dibutuhkan. Kecepatan berkecambah mengukur jumlah benih yang berkecambah pada tiga hari pertama setelah hipokotil muncul pertama kali. Perhitungan kecapatan berkecambah di hentikan pada hari ke 7. Koefisien perkecambahan (CG) dihitung dengan rumus (Kotowski, 1926).

Pengukuran Viabilitas spora dibuktikan dengan menggunakan metode umpan dengan menggunakan buah timun. Buah timun diletakkan pada bak perkecambahan tiga hari sebelum tanam dan 4 hari setelah inokulasi S. rolfsii. Sclerotia yang viabel akan berkecambah dan tumbuh dengan cepat pada buah timun. Media perkecambahan yang telah menunjukkan adanya pertumbuhan S. rolfsii dapat digunakan sebagai media perkecambahan dalam penelitian ini.

Data yang diperoleh Kemudian dianalisis dengan sidik ragam pada taraf nyata 5\% dan jika terdapat beda nyata antar perlakuan maka dilakukan uji jarak berganda Duncan's Multiple Range Test (DMRT), sedangkan data pengamatan periodik diamati dengan graik dan histogram.

\section{HASIL DAN PEMBAHASAN}

Viabilitas Spora

Semua unit percobaan memiliki spora yang viabel sehingga memiliki kemungkinan tinggi dapat menginfeksi benih cabai yang akan ditanam, ditandai dengan munculnya serabut putih pada buah timun. Serabut putih tersebut merupakan miselium dari Sclerotium rolfsii. Pada beberapa bagian dari miselium yang bersentuhan dengan buah timun terdapat sclerotium berwarna putih (gambar 1). Penggunaan timun sebagai umpan dikarenakan daging buah timun cenderung lunak sehingga sesuai untuk pertumbuhan S. roflsii. S. roflsii juga merupakan patogen yang menyebabkan busuk buah pada timun. Busuk buah pada timun yang disebabkan oleh $S$. rolfsii tergolong ke dalam penyakit minor, karena hanya menyebabkan kerusakan pada buah yang menempel pada tanah.

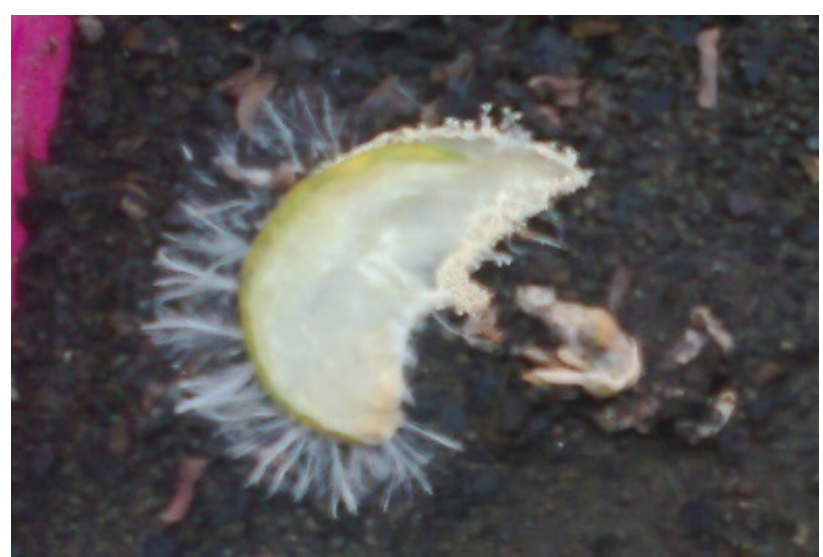

Gambar 1. Cendawan S. rolfsii yang hidup pada umpan buah timun

Kemungkinan cendawan Sclerotium rolfsii menginfeksi tanaman cabai juga diperkuat dengan perbandingan media tanam yang sesuai sebagaimana hasil penelitian Mulyati (2009) yang menyatakan bahwa cendawan Sclerotium rolfsii dapat tumbuh dan menginfeksi dengan lebih baik pada media dengan perbandingan pasir, tanah dan pupuk kandang 2:1:1. Agrios (1988) juga menyatakan cendawan Sclerotium rolfsii dapat tumbuh dengan baik pada media berpasir. Ketersediaan Oksigen yang tinggi pada medium berpasir mampu meningkatkan viabilitas Sclerotia.

\section{Serangan Sclerotium rolfsii}

Cendawan S. rolfsii menyerang persemaian dalam tiga katagori, yaitu germination loss, preemergence damping off dan post emergence damping off (Achmad, 1999). Germination loss dapat dibaikan karena bersumber dari benih unggul. Pengamatan pre-emergence damping off tidak dapat dibuktikan dalam penelitian ini. Pengamatan post emergence damping off menunjukkan tidak ada kejadian dilapangan. S. rolfsii diduga lebih menyerang benih yang baru mulai berkecambah dan 
belum keluar dari tanah bila dibandingkan dengan benih yang telah keluar dari tanah. Benih akan mengalami proses imbibisi sehingga benih lebih lunak, radikula yang muncul dari benih juga memiliki struktur yang lunak sehingga miselia S. rolfsii dapat menyebabkan preemergence damping off (Tjahjadi, 1989).

Kejadian post emergence damping off yang rendah diduga disebabkan oleh adanya senyawa antifungal seperti fenol dan kavikol sehingga memberikan perlindungan tambahan pada tanaman cabai terhadap serangan cendawan $S$. rolfsii (Nurmansyah, 2004). Selain itu, varietas branang memiliki ketahanan terhadap penyakit layu bakteri dan antraknosa, sehingga diduga ada senyawa antifungal yang juga mampu menghambat pertumbuhan S. rolfsii (Agrios, 1988). Senyawa tersebut tidak dapat bertahan sepenuhnya terhadap serangan cendawan S. rolfsii dibuktikan dengan daya berkecambah yang rendah pada kontrol.

\section{Daya Berkecambah}

Perendaman benih dengan ekstrak daun sirih 60\% pada perendaman 1 jam dan 2 jam terbukti mampu memberikan daya berkecambah yang lebih tinggi bila dibandingkan dengan kontrol (tabel 1). Senyawa aktif pada ekstrak daun sirih mampu mencegah serangan S. rolfsii melalui mekanisme pereduksian miselium, sehingga terjadi pemendekan pada ujung hifa, dan miselium lisis (Nurmansyah, 2004).

Perendaman benih dengan ekstrak daun sirih 60\% pada perendaman 1 jam dan 2 jam terbukti mampu memberikan daya berkecambah yang lebih tinggi bila dibandingkan dengan pemberian konsentrasi $80 \%$. Senyawa pada ekstrak daun sirih tidak hanya berpengaruh pada cendawan S. rolfsii namun juga pada benih melalui mekanisme penghambatan metabolisme sel, man- gakumulasi globula lemak di dalam sitoplasma sel, mengurangi jumlah mitokondira dan juga merusak membran nukleus (Nurmansyah, 2004).

Tabel 1. Rerata daya berkecambah benih cabai pada berbagai perlakuan

\begin{tabular}{lc}
\hline \multicolumn{1}{c}{ Perlakuan } & Daya Berkecembah (\%) \\
\hline EDS 40\% Perendaman 1 Jam & $56,67 \mathrm{ab}$ \\
EDS 40\% Perendaman 2 Jam & $50,00 \mathrm{ab}$ \\
EDS 40\% Perendaman $3 \mathrm{Jam}$ & $53,33 \mathrm{ab}$ \\
EDS 60\% Perendaman 1 Jam & $71,67 \mathrm{a}$ \\
EDS 60\% Perendaman $2 \mathrm{Jam}$ & $70,00 \mathrm{a}$ \\
EDS 60\% Perendaman 3 Jam & $58,33 \mathrm{ab}$ \\
EDS 80\% Perendaman 1 Jam & $35,00 \mathrm{~b}$ \\
EDS 80\% Perendaman 2 Jam & $38,33 \mathrm{~b}$ \\
EDS 80\% Perendaman 3 Jam & $35,00 \mathrm{~b}$ \\
Kontrol & $8,33 \mathrm{c}$ \\
\hline
\end{tabular}

Keterangan: Angka yang diikuti huruf yang sama menunjukkan tidak berbeda nyata berdasarkan uji lanjut DMRT pada taraf nyata $5 \%$ (transformasi arcsin). EDS = Ekstrak Daun Sirih

Lama perendaman benih akan membantu pematahan dormansi fisik, namun bila perendaman dilakukan dalam waktu yang cukup lama maka akan merusak benih. Schmidt (2000) menyatakan perendaman merupakan prosedur yang sangat lambat untuk mengatasi dormansi fisik, dan ada resiko besar bahwa benih akan mati jika dibiarkan dalam air sampai seluruh benih menjadi permeable. Selain itu, perendaman yang terlalu lama dapat menyebabkan benih mengalami anoksia atau kondisi kekurangan oksigen sehingga benih menjadi rusak (Schmidt, 2000).

\section{Vigor Benih}

Kecepatan berkecambah merupakan aspek penting yang akan memberikan vigor benih. Vigor benih sering diartikan sebagai kemampuan benih untuk tumbuh normal pada keadaan lingkungan yang suboptimal. Benih yang punya kecepatan berkecambah tinggi akan menghasilkan tanaman yang tahan terhadap lingkungan yang kurang menguntungkan bagi pertumbuhan tanaman. Ekspresi kecepatan berkecambah 
secara matematis yang umum digunakan adalah koefisien perkecambahan dan indeks vigor (Rineka, 1992). Seringkali pengukuran kecepatan berkecambah dilakukan dengan menggunakan metode first count juga digunakan untuk mengukur vigor benih.

Perlakuan ekstrak daun sirih 60\% dengan lama perendaman 1 jam dan 2 jam memberikan hasil indeks vigor, Koefisien berkecambah dan kecepatan berkecambah yang lebih baik bila dibandingkan dengan perlakuan lain (Tabel 2). Senyawa betlephenol dan kavikol mampu menghambat metabolisme, merusak membran nukleus dan mengurangi jumlah mitokondria, sehingga senyawa aktif pada daun sirih akan lebih memiliki kemampuan untuk merusak sel ketika konsentrasi yang diberikan terlalu tinggi. Senyawa betephenol dan kavikol yang terkandung dalam ekstrak daun sirih 40\% dan 60\% masih dapat ditolelir oleh benih, sehingga tidak menurunkan nilai indeks vigor benih (Nurmansyah, 2004).

Tabel 2. Hasil rerata indeks vigor, kecepatan berkecambah dan first count pada berbagai perlakuan

\begin{tabular}{lccc}
\hline Perlakuan & $\begin{array}{c}\text { Indeks Vigor } \\
\text { (jumlah/hari) }\end{array}$ & $\begin{array}{c}\text { Koefisien } \\
\text { Berkecambah } \\
\text { (\%/hari) }\end{array}$ & $\begin{array}{c}\text { Kecepatan } \\
\text { Berkecambah } \\
(\%)\end{array}$ \\
\hline EDS 40\% Perendaman $1 \mathrm{Jam}$ & $1,55 \mathrm{ab}$ & $13,10 \mathrm{a}$ & $41,66 \mathrm{a}$ \\
EDS 40\% Perendaman $2 \mathrm{Jam}$ & $1,31 \mathrm{abcd}$ & $12,39 \mathrm{a}$ & $26,66 \mathrm{abc}$ \\
EDS 40\% Perendaman $3 \mathrm{Jam}$ & $1,35 \mathrm{abc}$ & $11,00 \mathrm{a}$ & $23,33 \mathrm{abc}$ \\
EDS 60\% Perendaman $1 \mathrm{Jam}$ & $1,86 \mathrm{a}$ & $12,16 \mathrm{a}$ & $33,33 \mathrm{ab}$ \\
EDS 60\% Perendaman $2 \mathrm{Jam}$ & $1,73 \mathrm{a}$ & $10,83 \mathrm{a}$ & $23,33 \mathrm{abc}$ \\
EDS 60\% Perendaman 3 Jam & $1,35 \mathrm{abc}$ & $8,66 \mathrm{a}$ & $11,66 \mathrm{bcd}$ \\
EDS 80\% Perendaman $1 \mathrm{Jam}$ & $0,83 \mathrm{bcd}$ & $10,93 \mathrm{a}$ & $8,33 \mathrm{~cd}$ \\
EDS 80\% Perendaman $2 \mathrm{Jam}$ & $0,89 \mathrm{bcd}$ & $9,53 \mathrm{a}$ & $8,33 \mathrm{~cd}$ \\
EDS 80\% Perendaman $3 \mathrm{Jam}$ & $0,72 \mathrm{~d}$ & $3,33 \mathrm{~b}$ & $1,66 \mathrm{~d}$ \\
Kontrol & $0,23 \mathrm{e}$ & $4,63 \mathrm{~b}$ & $6,66 \mathrm{~d}$ \\
\hline
\end{tabular}

Keterangan: Angka yang diikuti huruf yang sama menunjukkan tidak berbeda nyata berdasarkan uji lanjut DMRT pada taraf nyata $5 \%$ (transformasi arcsin). EDS = Ekstrak Daun Sirih

Parameter vigor benih menurun seiring dengan semakin lamanya waktu pemberian konsentrasi ekstrak daun sirih (Tabel 2). Proses masuknya senyawa ke dalam sel dipengaruhi oleh konsentrasi larutan, semakin tinggi konsentrasi semakin cepat proses difusi. Selain itu molekul dengan ukuran besar membutuhkan waktu yang lebih lama untuk berdifusi bila dibandingkan dengan molekul dengan ukuran yang lebih kecil (Lambers 2008).

Nilai kontrol untuk indeks vigor, koefisien berkecambah dan kecepatan berkecambah memiliki nilai yang lebih rendah bila dibandingkan dengan perlakuan pemberian ekstrak daun sirih (Tabel 2). Benih tidak memiliki pertahanan terhadap serangan cendawan S. rolfsii. Nilai Vigor benih dipengaruhi oleh beberapa hal, salah satunya adalah keberadaan mikroorganisme penyebab penyakit. Benih dengan vigor yang tinggi lebih kuat terhadap serangan penyakit (Lita, 1985)

Hasil pengamatan indeks vigor, kecepatan berkecambah, dan first count memberikan hasil perlakuan tertinggi yang berbeda-beda. Indeks vigor memberikan hasil tertinggi pada perlakuan ekstrak daun sirih 60\% dengan lama perendaman 1 jam, sedangkan pada kecepatan berkecambah dan first count memberikan hasil tertinggi pada ekstrak daun sirih 40\% dengan lama perendaman 1 jam. Nilai indeks vigor berkaitan dengan jumlah benih yang berkecambah, semakin besar jumlah benih yang berkecambah maka semakin besar pula indeks vigor. Jumlah benih berkecambah akan memberikan nilai tambah pada indeks vigor. Nilai kecepatan perkecambahan tidak ada kaitannya dengan jumlah benih yang berkecambah, semakin lama waktu yang dibutuhkan benih untuk berkecambah maka akan memperkecil nilai dari koefisien perkecambahan. Nilai first count tidak berkaitan dengan jumlah benih berkecambah total karena batas waktu perhitungan first count dihentikan sebelum waktu perkecambahan selesai (Singh dkk, 2010). 


\section{SIMPULAN}

Perlakuan fungisida nabati ekstrak daun sirih yang mampu memberikan perlindungan terhadap serangan cendawan Sclerotium rolfsii adalah pemberian ekstrak daun sirih konsentrasi 60\% dengan lama perendaman 1 jam.

\section{DAFTAR PUSTAKA}

Achmad. 1999. Prospek Pengendalian Terpadu Penyakit Lodoh pada Persemaian Tanaman Kehutanan. J. Manajemen Hutan Tropika. $1: 1-9$

Agrios, G.N. 1988. Plant Pathology. NewYork. Academic Press. $635 p$

Copeland, L.O. 1976. Principles of Seed Science and Technology. Burgess Publ.Comp., Minneapolis.

Fery, R.L., and P.D. Dukes 2011. Shouthern Blight (Sclerotium rolfsii) of Cowpea: Genetic Charaterization of Two Sources of Resistence. International Journal of Agronomy. http://dx.doi. org/10.1155/2011/652404

Friska M.S.. 2008. Uji Efektivitas Beberapa Pestisida Nabati untuk Mengendalikan Penyakit Antraknosa (Colletotrichum capsici) Pada Tanaman Cabai (Capsicum annum) di Lapangan. Universitas Sumatra Utara. Medan.

Koesmiati, S. 1966. Daun sirih (Piper betle) sebagai desinfektan. Skripsi. Departemen Farmasi. Institut Teknologi Bandung. Bandung.

Kotowski, F. 1926. Temperature relations to germination of vegetable seed. Proceedings of the American Society for Horticultural Science 23:176-184

Lambers, H., F.S. Chapin., T.L. Pons. 2008. Plant Physiological Ecology. Springer. New York.

Lita S. 1985. Teknologi Benih. Rajawali. Jakarta.

Madhavi, GB., SL. Battiprolu. 2011. Integrated Disease Management of Dry Root Rot of Chilli Incited by Sclerotium rolfsii (Sacc.). Int. J. of Plant Anim. and Env. 1(2):31-37

Mulyati, S. 2009. Pengaruh Kandungan Pasir pada Media Semai Terhadap Penyakit Rebah Kecambah (Sclerotium rolfsii Sacc) pada Persemaian Tanaman Cabai. J. Agronomi 13(1): 45-50

Nurhayati. 2007. Pertumbuhan Colletotrichum capsici Penyebab Antraknosa Buah Cabai pada Berbagai Media yang Mengandung Ekstrak Tanaman. J. Rafflesia. 9(1): 32-35

Nurmansyah. 2004. Pengaruh Penambahan Minyak Serai Wangi dan Limbah Kayu Manis terhadap Daya Anti Fungi Pestisida Nabati Sirih. Prosiding Ekspose Teknologi Gambir Kayu Manis dan Atsiri. Hal.86-92

Rineka Cipta. 1992. Teknologi Benih: Pengelolaan Benih dan Tuntunan Praktikum. Rineka Cipta. Jakarta.

Schmidt, L. 2000. Guide to Handling of Tropical and Subtropical Forest Seed. Danida Forest Seed Centre. Denmark.

Saxena, M., N.K. Khare, P. Saxene, K.V. Syamsundar, dan S.K. Srivastava. 2014. Antimicrobial Activity and Chemical Composition of Leaf Oil in Two Varieties of Piper Betle From Northern Plains of India. Journal of Scientific \& Industial Research. 73:95-99
Septana, N. Agustin, A.M. Ar-Rozi. 2012. Kinerja Produksi dan Harga Komoditas Cabai Merah. http://pse.litbang.pertanian. go.id/ind/pdffiles/anjak_2012_10.pdf, diakses pada 13 Maret 2015.

Singh, N.I., K.K. Verma and, J.S. Chauhan 2010. Comparative Efficacy of Different Vigour Test Parameters of Pea (Pisum sativum L.) Seed Testing. Libyan Agric. Res. Cen. J. Intl., 1 (5): 332-335

Soesanto, L. 2008. Pengantar Pengendalian Penyakit Tanaman. rajawali Pers. PT. Raja Grafindo Persada. Jakarta.

Tjahjadi, N. 1989. Hama dan Penyakit Tanaman. Kanisius. Yogyakarta.

Zaidun. 2006. Bahan Tumbuhan Rawa yang Berpotensi Sebagai Fungisida Nabati. Temu Teknis Tenaga Fungsional 